УДК 628:631.4:502.65

DOI: $10.15587 / 2313-8416.2015 .37400$

\title{
КАНЦЕРОГЕННІ РЕЧОВИНИ В СУЧАСНИХ КОСМЕТИЧНИХ ЗАСОБАХ
}

\author{
(C) О. В. Полковенко
}

У статті надана інформація про збільшення захворюваності і смертності від раку у всьому світі виілому і в Україні зокрема. Значну роль у стимулюванні розвитку раку грають зовнішні каниерогени. Серед них є речовини, які знаходяться у складі сучасних косметичних засобів. Отже, знати про такі канцерогени і не допускати придбання косметичних продуктів, щзо їх містять, дозволяє знизити ризик захворювання на рак

Ключові слова: здоров'я, рак, світ, Україна, захворювання, ризик, хімічні речовини, спосіб життя, канцерогени, косметичні засоби

The method of the presented research was a scientific analysis of literary data. In the article the given information is about the increase of morbidity and death rate from a shrine in the whole world and in Ukraine in particular and to influence on this situation of external carcinogens which some constituents of cosmetic facilities are among.

Results of researches. By basic obvious carcinogens which are contained in modern cosmetic products are: DEA Diethanolamine, khimikat, which is used not only in creams but also in clearing Cosmetology.

MEA (Monoethanolamine) chemical absorbent, used in Cosmetology for the delete of gases. TEA (Trithanolamine) - used as konservant, BHA (Salicylic acid (Beta-oksikislota)) dissolves fat and able to primp and clear muddy pores. BHT (Butylated Hydroxytoluene) - used as an antioxidant in creams and in a meal (E321).

Conclusions. The Oncologic diseases occupy conclusions leading place in the death rate of people all over the world. Scientifically grounded is that matters which stimulate development of cancer tumours are, and such matters name carcinogens. . Some of such mortally hazardous substances can be component parts of modern cosmeticology facilities. And as Cosmetology exists already thousand years and, probably, it will exist, while living though one woman, for today vitally a necessity is knowledge and ability to use information about the constituents of cosmetic facilities and feature of their application. Only such approach will allow to avoid harmful consequences for a health and eventually to save the life

Keywords: health, cancer, world, Ukraine, disease, risk, chemical matters, way of life, carcinogens, cosmetic products

\section{1. Вступ}

Рак - це безконтрольне зростання аномальних клітин у організмі. Клітини є свого роду цеглинками, 3 яких «побудовано» все живе. Рак починає рости в здорових клітинах організму. У нормі клітини розмножуються, коли вони потрібні організму, i вмирають, коли потреба в них зникає. Рак розвивається, коли ріст клітин виходить 3-під контролю організму, $\mathrm{i}$ вони розмножуються дуже швидко.

Існує безліч різновидів раку. Він може почати розвиватися майже в будь-яких органах і тканинах, наприклад, в легенях, товстій кишці, молочних залозах, в кістках або нервової тканини.

\section{2. Огляд літератури}

Статистика говорить про те, що за останні 100 років за рівнем захворюваності та смертності в світі онкопатологія перемістилася з десятого місця на друге, поступаючись лише хворобам серцевосудинної системи. За даними ВООЗ, щороку знову хворіють 10 млн чоловік. Як стверджує ВООЗ, смертність від раку до 2030 року зросте на $45 \%$, в порівнянні з рівнем 2007 року [1-4].

Як заявили представники ВООЗ, кількість смертельних випадків, викликаних раком, буде в Європі поступово збільшуватися. При цьому, за їх словами, можна було б запобігти до 40 \% випадків захворювання раком, якби люди вели здоровий спосіб життя і поліпшили механізми виявлення раку. У країнах Свропи до ризику захворювання раком найбільшою мірою схильні люди 3 низьким i середнім рівнем доходу, які в меншій мірі усвідомлюють фактори ризику, а також мають обмежений доступ до ефективної медичної допомоги. За словами представників ВООЗ, 72 \% смертельних випадків, викликаних раком, зафіксовані в країнах 3 низьким або середнім рівнем доходу на душу населення [2, 3].

В Україні ситуація це більш невтішна. Так, Україна посідає другє місце в Європі за темпами поширення раку. Щорічно в Україні більше 160 тис. чоловік дізнаються, що вони онкохворі. Щороку від раку помирають близько 90 тис. осіб, з них 35 \% люди працездатного віку. Щодня в Україні захворюють раком 450 людей, 3 них гинуть 250. Щогодини реєструється понад 20 нових випадків захворювання, а 10 жителів України помирають від раку. Ризик розвитку онкологічних захворювань становить $27,7 \%$ для чоловіків і 18,5 \% для жінок. Злоякісні новоутворення вражають в Україні кожного четвертого чоловіка i кожну шосту жінку [5-7, 10].

За розрахунками фахівців, до 2020 року кількість вперше захворілих на рак в Україні перевищить 200 тис. 
За даними Інституту раку в 2009 році на обліку онкологічних установ складалося 961183 особи, з них 338635 чоловіки і 622548 жінки.

За останні десять років кількість хворих зросла на $25 \%$, загальна чисельність населення скоротилася на 4 млн. чоловік. Онкологічна захворюваність стабільно зростає на 2,6-3 \% на рік, і рак продовжує «молодіти». Здавалося б, за цими показниками ми не сильно відрізняємося від розвинених країн, проте слід враховувати, що середня тривалість життя українців на 10-20 років нижча, а захворюваність на рак істотно зростає після 50 років. I далеко не кожен українець доживає до «свого раку», вмираючи від інших причин [6].

3. Канцерогенні речовини в сучасних косметичних засобах як одна 3 причин збільшення захворюваності на онкологічні хвороби в усьому світі та в Україні

Причини багатьох типів раку, як і раніше залишаються невідомими. На сьогодні велика частина смертей від раку припадає на рак легенів. Фактори, що стимулюють виникнення i розвиток онкологічних захворювань, називають канцерогенними. Вони поділяються на зовнішні i внутрішні $[1,3,5,11]$.

Зовнішні канцерогенні фактори схематично можна розділити на три основні групи: фізичні, хімічні й біологічні.

Необхідно однак підкреслити, що механізм дії зовнішніх канцерогенних факторів на клітину остаточно не з'ясований. А тому відсутня можливість отримання переконливих доказів їхнього канцерогенного впливу на організм людини, за винятком хіба що аналітичних епідеміологічних досліджень [11].

3 фізичних факторів особливої уваги заслуговують різні випромінювання. В результаті ядерних випробовувань, аварій на атомних електростанціях, атомних кораблях і підвідних човнах, розширення сфери діяльності людини, пов'язаної з використанням джерел випромінювання, великих масштабів набуло поширення радіонуклідів. Вони можуть попадати в організм із питною водою, продуктами харчування. А оскільки період напіврозпаду основних радіоактивних елементів (кобальт, цезій, стронцій) обчислюється десятками років, то їхня патогенна дія в організмі хронічна, довготривала. До цього варто додати, що внаслідок зменшення озонового шару атмосфери Землі й появи так званих "озонових дір" збільшується потік і активність ультрафіолетового проміння Сонця [5, 6, 11].

Науці відомо, переважно в експериментах на тваринах, велика кількість хімічних речовин, що можуть бути канцерогенними. До них відносяться ароматичні вуглеводи (бензопірен, бензантрацен), ароматичні аміни (анілінові барвники, нафтиламін), азотисті сполуки, отрутохімікати (гербіциди, інсектициди), мінеральні добрива, флавоноїди, азбест і т. п. Джерелом більшості канцерогенів у навколишньому середовищі є викиди промислового виробництва. Через забруднені грунт, воду, повітря, біологічні організми канцерогени попадають на шкіру, в легені, а 3 харчовими продуктами - у внутрішнє середовище організму. Канцерогенні речовини утворюються при згорянні тютюну i вдихуються при курінні $[7-9,11]$.

\section{4. Результати досліджень}

Але крім цього, існують канцерогенні речовини, які вводять в свій організм люди, що ведуть здоровий спосіб життя i, по можливості, мінімізують вплив забрудненого навколишнього середовища на своє здоров'я. Це речовини, що містяться в сучасних косметичних засобах $[4,7,8]$.

Вони додаються в косметичні засоби з метою поліпшення їх структури, продовження терміну зберігання, збільшення кількості піни тощо. Але, разом з цим, вони згубно впливають на наш організм, тим більше, що ми користуємося косметикою впродовж десятиліть. Не є секретом, що найчастіше косметичні засоби обираються, спираючись на рекламні повідомлення у різних ЗМІ. Однак, слід зазначити, що переважна більшість покупців не читає склад продуктів, що представлений на етикетках, або, якщо і читає, то не володіє інформацією про те, які складові кремів, шампунів, або гелів для душу можуть бути канцерогенами, отже смертельно небезпечними. Тому в представленому дослідженні надаються відомості про найбільш розповсюджені і одночасно найбільш небезпечні канцерогенні речовини, що можуть бути у складі косметичних засобів $[4,8,9]$.

Розрізняють скриті та явні канцерогени. Перші самі по собі не є шкідливими, але вступаючи в реакцію 3 деякими речовинами, утворюють небезпечні сполуки .

Так, наприклад, DEA(діетаноламін), TEA (триетаноламін) - хімікати, що містяться у миючих засобах, вступають в реакцію із нітратами утворюючи інші речовини - нітрозаміни (сильні канцерогени). Інша група небезпечних хімікатів має назву Formaldehyde Releasers, (речовини, що вивільнюють формальдегід) До них належать Bronopol - (бронопол), Quaternium 15 - (кватерніум15), Imidazolidinyl Urea - (імідазодініл-моче-вина), Diazolidinyl Urea - (діазолідініл-мочеви-на), DMDH Hydantoin - (DMDH-гідантоїн). Самі по собі, вони не $\epsilon$ канцерогенами, але в усіх випадках, вони або розкладаються у флаконі чи тюбику, або прямо у вас на шкірі й вивільнюють при цьому формальдегід, явності якщо $\epsilon$ потужним канце-рогенгом. Крім цього, $\epsilon$ i явні канцерогени, тобто речовини, які безпосередньо, без будь-яких хімічних реакцій, стимулюють розвиток онкологічних новоутворень.

DEA Diethanolamine, хімікат, який використовується не тільки в кремах, але і в очищуючій косметиці - лосьйонах, вершках, молоці, пінці i іншій косметиці. DEA набула широкого поширення, за рахунок утворення хорошої піни i відмиваючій здатності. Сам по собі компонент DEA не шкідливий, але в реакції з іншими компонентами в косметичній формулі, здатний сформувати надзвичайно могутню канцерогенну речовину, зване 
nitrosodiethanolamine

поглинається через шкіру i викликає ракові захворювання.

MEA (Monoethanolamine) хімічний абсорбент, використовується в косметиці для видалення газів $\mathrm{H}_{2} \mathrm{~S}$ і CO, у складі кремів, як і DEA використовується як емульгатор.

TEA (Trithanolamine) - використовується як консервант, може реагувати 3 нітратами і сформувати канцерогенну речовину nitrosamines, що легко проникає крізь шкіру i викликає ракові захворювання.

ВНА (Саліцилова кислота (Бета-оксикислота)) розчиняє жир і здатна вбиратися і очищати забруднені пори. Вона зменшує кількість угрів i запобігає їх появі, сприяє вибілюванню. У великих дозах саліцилова кислота $є$ канцерогеном і мало хто знає, що лікування препаратами що містять саліцилову кислоту повинно проводиться не постійно, а курсами, з перервами не менше місяця.

BHT (Butylated Hydroxytoluene) - вико ристовується як антиокислювач в кремах і в їжі (Е321). Зв'язується 3 молекулами кисню, перешкоджаючи тим самим окисленню жирів. $Є$ канцерогеном. Заборонений для додавання в їжу в Японії, Румунії, Швеції, Австралії і США (у дитячому харчуванні) [7-9].

Отже, для запобігання захворювання на онкологічні хвороби, окрім загальновідомих рекомендацій щодо здорового способу життя, правильного харчування та зменшення впливу забруднених складових наколишнього середовища, слід додержуватися таких правил:

Купувати косметичні засоби лише у великих спеціалізованих магазинах, оскільки там більший шанс того, щона полиці не потрапить засіб із забороненими небезпечними складовими.

Обов'язково уважно читати склад на етикетці. Якщо нема етикетки 3 українським перекладом, краще відмовитися від купівлі даного засобу, оскільки таким чином виробники можуть приховати наявність небезпечних ,в тому числі канцерогенних, речовин у складі.

I нарешті: наша освідченість - запорука нашого здоров'я і життя, оскільки лише ми можемо не купити косметичний продукт зі смертельними складовими, оскільки абсолютну більшість засобів перед випуском в масове виробництво виробники на предмет канцерогенності не перевіряють.

\section{5. Висновки}

Онкологічні захворювання займають провідне місце у смертності людей по всьому світу. Науково обгрунтованим $\epsilon$ те, що існують речовини, які стимулюють розвиток ракових пухлин, i такі речовини називають канцерогенами. . Деякі з таких смертельно небезпечних речовин можуть бути складовими частинами сучасних косметологічних засобів. I оскільки косметика існує вже тисячі років i, напевно, буде існувати, допоки живе хоч одна жінка, на сьогодні життєво необхідним є знання і вміння користуватись інформацією про складові косметикних засобів і особливості їх застосування. Лише такий підхід дозволить уникнути шкідливих наслідків для здоров'я і врешті-решт зберегти своє життя.

\section{Література}

1. Boyle, P. Epidemiology of colorectal cancer [Text] / P. Boyle, M. E. Leon // British Medical Bulletin. - 2002. Vol. 64, Issue 1. - P. 1-25. doi: 10.1093/bmb/64.1.1

2. Ferlay, J. Cancer Incidence and Mortality Worldwide [Text] / J. Ferlay, H. R. Shin, F. Bray et al. // IARC CancerBase. - 2010. - Vol. 10. - P. 334-346.

3. Ferlay, J. Estimates of cancer incidence and mortaon in Europe in 2008 [Text] / J. Ferlay, D. M. Parkin // European Journal of Cancer. - 2010. - Vol. 46, Issue 4. - P. 765-781. doi: 10.1016/j.ejca.2009.12.014

4. Siegel, R. Cancer statistics [Text] / R. Siegel, D. Naishadham, A. Jemal // CA: A Cancer Journal for Clinicians. 2012. - Vol. 62, Issue 1. - P. 10-29. doi: 10.3322/caac.20138

5. Марголіна, А. А. Нова Косметологія [Текст] / А. А. Марголіна. - Красноярск: Красноярське книжкове видавництво, 2006. - Р. 132-145.

6. Щепотін, I. Б. Порівняльна характеристика стану ураження злоякісними новоутвореннями міського та сільського населення України [Текст] / І. Б. Щепотін, 3. П. Федоренко, А. В. Гайсенко // Клин. онкол. - 2011. № $1 .-$ C. $4-8$.

7. Федоренко, 3. П. Особенности трендовых моделей заболеваемости раком грудной железы в Украине после аварии на ЧАЭС [Текст] / 3. П. Федоренко, Л. О. Гулак, А. У. Рыжов и др. // Клиническая онкология. 2012. - № 5 (1). - Р. 11-16.

8. Войткевич, С. А. Эфірні масла, ароматізатори, консерванти [Текст] / С. А. Войткевич. - М.: Дрофа, 2000. $-67 \mathrm{c}$

9. Жаркова, С. О. Оцінка тенденції споживання протипухлинних препаратів та захворюваності на рак шлунка в Україні та світі [Текст] / С. О. Жаркова, А. С. Демченко, М. В. Подгайна, В. М. Хоменко // Фармацевтичний журнал. - 2013. - № 3. - С. 9-15.

10. Статистика онкологічних захворювань в Україні [Електроний ресурс] / Режим доступу: http://diapharma.ua/ articles/statistika-onkologichnih-zahvoryuvan-v-ukrayini

11. Основні причини й поширеність злоякісних пухлин [Електроний ресурс] / Режим доступу: http://www.cancer.ic.ck.ua/u_index_3_1.htm

\section{References}

1. Boyle, P., Leon, M. E. (2002). Epidemiology of colorectal cancer. British Medical Bulletin, 64 (1), 1-25.

doi: $10.1093 / \mathrm{bmb} / 64.1 .1$

2. Ferlay, J. Shin, F. B. et al. (2010). Cancer Incidence and Mortality Worldwide. IARC CancerBase, 10, 334-346.

3. Ferlay, J., Parkin, D. M. (2010). Estimates of cancer incidence and mortaon in Europe in 2008. European Journal of Cancer, 46 (4), 765-781. doi: 10.1016/j.ejca.2009.12.014

4. Siegel, R. D. Naishadham, A. J. (2012). Cancer statistics. CA: A Cancer Journal for Clinicians, 62 (1), 10-29. doi: 10.3322/caac. 20138

5. Margolina, A. A. (2006). Nova Kosmetologija. Krasnoyarsk: Krasnoyarske knizhkove vidavnitstvo, 132-145.

6. Schepotin, I. B., Fedorenko, Z. P., Gaicenko, A. V. (2011). Porivnalna kharakteristika stanu urazhennia zlojakisnimi novoutvorennjami miskogo ta silskogo naselennja Ukraini. Klinicna. Onkologija, 1, 4-8.

7. Fedorenko, Z. P., Gulak, L. O., Rizhov, A. U. et. al. (2012). Osobennosti trendovikh modelej zabolevaemosti rakom grudnoj zhelezi $\mathrm{v}$ Ukraine posle avariji na CHAES, $5(1), 11-16$. 
8. Voitkevitch, S. A. (2000). Efirni masla, arimatizatiri, konservanti. Moscow: Drofa, 67.

9. Zharkova, C. O., Demchenko, A. C., Podgaina, M. V., Khomenko, V. M. (2013). Ocinka tendencij spozhivannj protipukhlinnikh preparativ ta zakhvoruvanosti na rak shlunka v Ukraini ta cviti. Pharmacevtichiy zhurnal, 3, 9-15.
10. Statystyka onkologichnyh zahvorjuvan' v Ukrai'ni. Available at: http://diapharma.ua/articles/statistikaonkologichnih-zahvoryuvan-v-ukrayini

11. Osnovni prychyny j poshyrenist' zlojakisnyh puhlyn. Available at: http://www.cancer.ic.ck.ua/ u_index_3_1.htm

Рекомендовано до публікації д-р біол. наук Шейко В. I. Дата надходження рукопису 23.01.2015

Полковенко Ольга Володимирівна, кандидат біологічних наук, доцент, кафедра анатомії і фізіології людини, Інститут людини Київського університету імені Бориса Грінченка, вул. Бульварно-Кудрявська, 18/2, м. Київ, Україна, 04053

E-mail: tpluso@ukr.net

УДК 612.015.2:591.05:599.323.4:176

DOI: $10.15587 / 2313-8416.2015 .37406$

\title{
ВПЛИВ ІМУНОМОДУЛЯТОРІВ ПРИРОДНОГО ПОХОДЖЕННЯ НА ПОКАЗНИКИ КЛІТИННОГО ІМУНІТЕТУ КРОВІ КРОЛИКІВ ЗА УМОВ СТРЕСУ
}

\author{
(C) С. С. Грабовський, О. С. Грабовська
}

Досліджували T- і В-лімфоцити кроликів при використанні імуномодуляторів за умов стресу. Введення імуномодуляторів має стимулювальний вплив на кількість $T$ - $і$ B-лімфоцитів $і$ функиіональну активність $T$ - $і$ В-клітинного імунітету в крові кроликів перед їх забоєм. Отримані результати можуть бути використані для підвищення резистентності організму, корекції та зняття впливу передзабійного стресу тварин.

Ключові слова: кролики, передзабійний стрес, екстракти селезінки, T- і В-лімфоцити

Aim. The article is devoted to the researching of $T$ - and B-lymphocytes relative amount in the rabbits blood after using of plant and animal origin immunomodulators under stress.

Methods. The relative amount of $T$ - and B-lymphocytes and its some populations in the reaction of spontaneous rosetting with the ram erythrocytes in the blood was determined. Thus, the differentiated count of rosetting lymphocyte with the different functional activity degree was conducted. The spleen extracts added to the rabbits feed by aerosol introduction method.

Results. T- and B-lymphocytes amount and functional activity $T$ - and B-cell immunity was stimulated after additional supplementary to rabbits diet of experimental group natural origin immunomodulators. Spleen extract polyamines as the immunomodulators and antistressors most effectively influenced on some $T$-and B-cell immunity indices before slaughter: amount of T-(Th-0) and B-(3-5)lymphocytes were decreased.

Conclusions. The results which obtained in experiment can to use in researches of cell immunity indices on farm animals for organism resistance increasing and correction their pre-slaughter stress.

Keywords: rabbits, pre-slaughter stress, spleen extracts, T- and B-lymphocytes

\section{1. Вступ}

Функціонуючою основою імунної системи $\epsilon$ складний комплекс імунокомпетентних клітин (Т-, Влімфоцити, макрофаги). На відміну від В-лімфоцитів, здатних розпізнавати антигени в розчині і зв'язувати білкові, полісахаридні і ліпопротеїдні розчинні антигени, Т-лімфоцити здатні розрізняти тільки короткі пептидні фрагменти білкових антигенів [1]. У попередніх дослідженнях нами встановлено вплив передзабійного стресу на клітинний імунітет та рівень кортизолу у крові щурів [2].

\section{2. Постановка проблеми}

У літературі недостатньо висвітлені питання про вплив передзабійного стану тварин на окремі показники імунітету. Слід пам'ятати, що перед забоєм сільськогосподарських тварин не можна використовувати препарати, які б мали негативний вплив на організм людини після споживання продукції від цих тварин. Саме тому у дослідженнях ми використали біологічно активні речовини природного походження - екстракт селезінки. Метою роботи було встановити чи підвищується резистентність та імунітет у кроликів при одночасному зменшенні передзабійного стресу за використання екстракту селезінки.

\section{3. Літературний огляд}

3 літературних джерел відомо про вплив стресу різного характеру на Т- і В-клітинний імунітет 